\title{
Effect of corneal biomechanical properties on surgically-induced astigmatism and higher-order aberrations after cataract surgery
}

\author{
Efeito das propriedades biomecânicas da córnea no astigmatismo induzido cirurgicamente \\ e nas aberrações de alta ordem após a cirurgia de catarata
}

Mustafa Koç ${ }^{1}$, ÇaĞri İlhan ${ }^{1}$, Yaran Koban $^{2}$, Kemal Özülken $^{3}$, İrfan Durukan ${ }^{4}$, Pelin Yilmazbaş $^{1}$

\begin{abstract}
Purpose: To investigate the relationship between biomechanical properties of the cornea and postoperative refractive changes in patients with low-level astigmatism after cataract surgery.

Methods: This prospective study recruited patients undergoing cataract surgery involving 2.8-mm superior incisions. Biomechanical properties of the cornea were evaluated preoperatively using the Ocular Response Analyzer, and corneal profiles were evaluated using a Scheimpflug system (Pentacam HR). Topographic astigmatism, total corneal aberrations (TCA) and higher-order corneal aberrations (HOCA) analyses were performed preoperatively and during 1-and 3-month postoperative exams. The incidences of surgically-induced astigmatism (SIA) and HOCAs were calculated using vector analyses. Associations of the preoperative biomechanical properties of the cornea with SIA and HOCAs were evaluated.

Results: This study included 28 eyes of 28 patients. The preoperative corneal hysteresis $(\mathrm{CH})$ was $8.68 \pm 1.86 \mathrm{mmHg}$, and the corneal resistance factor (CRF) was $8.66 \pm 1.61 \mathrm{mmHg}$. At the 1 -month postoperative evaluation, significant changes were observed in HOCAs ( $p=0.023)$, TCAs ( $p=0.05)$, astigmatism ( $p=0.02)$, and trefoil ( $p=0.033)$; in contrast, differences in coma $(p=0.386)$ and spherical aberration (SA) were not significant $(p=0.947)$. At the 3 -month visit, significant changes were only observed in TCAs $(p=0.02)$ and HOCAs $(p=0.012)$. No relationships between the preoperative corneal hysteresis and corneal resistance factor and postoperative SIA and HOCA were identified, other than a positive correlation between the 3-month postoperative incidence of corneal hysteresis and spherical aberration.

Conclusions: Despite the observed lack of relationships of preoperative biomechanical properties of the cornea with SIA and postoperative aberrations (except for SA), further studies involving larger patient groups are needed to explore the unexpected refractive deviations after cataract surgery.
\end{abstract}

Keywords: Cornea/surgery; Cornea/physiopathology; Cataract extraction; Lens implantation, intraocular; Biomechanical phenomena/physiology; Corneal wavefront aberration/physiopathology; Astigmatism/etiology

\section{RESUMO}

Objetivo: Investigar a relação entre as propriedades biomecânicas da córnea e as mudanças refrativas pós-operatórias em pacientes com baixa astigmatismo após a cirurgia de catarata.

Método: Neste estudo prospectivo, recrutamos os pacientes submetidos a cirurgia de catarata com incisões superiores de $2,8 \mathrm{~mm}$. As propriedades biomecânicas da córnea foram avaliadas no pré-operatório pelo Ocular Response Analyzer (ORA, Reichert, EUA) e o perfil corneano foi avaliado por um sistema Scheimpflug (Pentacam HR, Oculus Optikgeräte, $\mathrm{GmbH}$ ). As avaliações do astigmatismo topográfico e das aberrações corneanas de alta ordem (HOCA) foram feitas no pré-operatório e no 10 e $3^{\circ}$ mês pós-operatório. O astigmatismo induzido cirurgicamente (SIA) e aberrações corneanas de alta ordem foram calculados pela análise vetorial. Associações das propriedades biomecânicas da córnea no pré-operatório com astigmatismo induzido cirurgicamente e aberrações corneanas de alta ordem foram avaliadas.

Resultados: $O$ estudo foi realizado em 28 olhos de 28 pacientes. A histerese corneana (CH) pré-operatória foi $8,68 \pm 1,86 \mathrm{mmHg}$, e o fator de resistência da córnea (CRF) foi de 8,66 $\pm 1,61 \mathrm{mmHg}$. No pós-operatório de 1 mês houve mudanças significativas aberrações corneanas de alta ordem $(p=0,023)$, aberração total $(p=0,05)$, astigmatismo $(p=0,02)$ e trifóglio $(p=0,033)$, mas as diferenças em coma $(p=0,386)$ e aberração esférica (SA) foram insignificantes $(p=0,947)$. No terceiro mês, a única mudança significativa foi em RMS total $(p=0,02)$ e aberração total $(p=0,012)$. Não houve relação entre histerese corneana e o fator de resistência da córnea pré-operatórios e astigmatismo induzido cirurgicamente e aberrações corneanas de alta ordem pós-operatórios, além de uma correlação positiva entre o histerese corneana e o aberração esférica do 3ำ ês pós-operatório.

Conclusões: Apesar de não haver relação entre as propriedades biomecânicas pré-operatórias da córnea e astigmatismo induzido cirurgicamente e aberrações (exceto SA) após a cirurgia em nosso estudo, são necessários mais estudos com grupos de pacientes maiores de explicar os erros refrativos inesperados após a cirurgia de catarata.

Descritores: Córnea/cirurgia; Córnea/fisiopatologia; Extração de catarata; Implante de lente intraocular; Fenômenos biomecânicos; Aberrações de frente de onda da córneal fisiopatologia; Astigmatismo/etiologia

\section{INTRODUCTION}

The $21^{\text {st }}$ century will be characterized by the development of sophisticated intraocular lenses (IOLs). Such lenses will be developed with the basic aim of allowing patients to achieve both close and distance vision without a requirement for corrective glasses ${ }^{(1)}$. Although these lenses reduce internal aberrations and compensate for corneal astigmatism and aberrations, these benefits are minimized in the context of an uncorrected astigmatism exceeding 0.75 diopters (D). In addition, image quality is significantly affected in the presence of other higher-order corneal aberrations $(\mathrm{HOCAs})^{(2)}$. The associated
Submitted for publication: January 23, 2016

Accepted for publication: July 23, 2016

Ophthalmology Department, Ulucanlar Eye Training and Research Hospital, Ankara, Turkey.

Ophthalmology Department, Kafkas University Kars, Turkey.

${ }^{3}$ Dünyagöz Hospital, Ankara, Turkey.

Kayserigöz Hospital, Kayseri, Turkey.
Funding: No specific financial support was available for this study.

Disclosure of potential conflicts of interest: None of the authors have any potential conflicts of interest to disclose.

Corresponding author: Mustafa Koç. Ulucanlar Göz Eğitim Araștırma Hastanesi - SamanpazarıAltındağ. Ankara, 06120 - Turkey - E-mail: drmukoc@hotmail.com

Approved by the following research ethics committee: Ankara Numune Training and Research Hospital (\# 20796219-E-14-174). 
surgical procedure remains the primary cause of induced corneal changes, especially astigmatism and aberrations ${ }^{(3)}$.

Induced refractive corneal changes after cataract surgery depend mainly on the incision location and width ${ }^{(3,4)}$. However, various undefined factors might also affect refractive outcomes. In some cases, surgically-induced corneal changes are more extensive than expected. Such changes impair visual outcomes and patient satisfaction, especially when multifocal or toric IOLs (premium IOLs) are used. Hence, the identification of other factors that might influence the impact of a surgical procedure on corneal optical properties is crucial to achieve perfect refractive results from premium cataract surgery ${ }^{(5)}$.

The present study aimed to investigate the effects of biomechanical properties of the cornea on refractive changes after cataract surgery in patients with low-level astigmatism.

\section{METHODS}

\section{Subjects}

This prospective, non-randomized study was conducted at the Ulucanlar Eye Training and Research Hospital from July to November 2014, in accordance with the Declaration of Helsinki. Approval was obtained from the ethics committee of Ankara Numune Education and Training Hospital. All patients provided written informed consent after receiving a thorough explanation of the procedure, risks, and possible complications of the study.

Patients aged $40-75$ years who had visually significant cataracts according to the Lens Opacification Classification System III were included in the study. For patients with cataracts in both eyes, the eye with the lowest sharpness of vision was included in the study. Exclusion criteria included a history of ocular surgery or ocular surface disease and astigmatism of the frontal corneal surface exceeding $0.50 D^{(6,7)}$ Patients with diabetes were also excluded from the study because the blood glucose concentrations associated with this disease can alter corneal biomechanical properties ${ }^{(8)}$.

\section{SURGICAL TECHNIQUE}

All patients underwent uneventful cataract surgeries under topical anesthesia, and all procedures were performed by the same surgeon (MK). A 2.8-mm superior clear corneal incision and two 1 -mm side port incisions $90^{\circ}$ from the main port were created. The stop-and-chop method was used for phacoemulsification, and all surgeries were performed using the same phaco machine (Infinity Vision System, Alcon Laboratories Inc., Ft. Worth, TX, USA). All patients received a single hydrophobic acrylic IOL (AcrySof SA60BM; Alcon Laboratories Inc.). All incisions were sealed with stromal hydration, and none of the patients received corneal sutures.

\section{Patient assessment}

Examinations were performed preoperatively and postoperatively at 1 and 7 days and 1 and 3 months postoperatively. Refraction, slit-lamp, and fundus examinations, optical analysis of corneal astigmatism and HOCAs with a Scheimpflug rotating camera (Pentacam HR; Oculus Optikgeräte GmbH, Wetzlar, Germany), and biomechanical measurements with an Ocular Response Analyzer (ORA; Reichert Ophthalmic Instruments, Depew, NY, USA) were performed preoperatively and at 1 and 3 months postoperatively. Surgically-induced astigmatism (SIA), coma, and trefoil were calculated following a conventional vectorial analysis. Corneal aberrations were evaluated in the central 6.0-mm zone.

\section{Statistical analysis}

The Statistical Package for Social Science (SPSS) version 18.0 (SPSS, Inc., Chicago, IL, USA) was used for the data analyses. The Mann-Whitney $U$ test was used for data comparison. Spearman's test was used for correlation analyses. P values $<0.05$ were considered to be statistically significant.

\section{RESULTS}

Twenty-eight eyes of 28 patients were analyzed in this study. The demographic characteristics of the participants are summarized in table 1. The preoperative astigmatism level was $0.23 \pm 0.12 \mathrm{D}$. Thirteen patients had no astigmatism. Astigmatism with the rule was observed in eight eyes (flat axis: $0-30^{\circ} / 150-180^{\circ}$ ), astigmatism against the rule was observed in two eyes (flat axis: $60-120^{\circ}$ ), and oblique astigmatism (flat axis: $30-60^{\circ} / 120-150^{\circ}$ ) was observed in 5 eyes. The preoperative corneal hysteresis $(\mathrm{CH})$ was $8.68 \pm 1.86 \mathrm{mmHg}$, and the corneal resistance factor (CRF) was $8.66 \pm 1.61 \mathrm{~mm} \mathrm{Hg}$. The preoperative and postoperative HOCA results, as well as the 1 - and 3 -month postoperative SIAs, are listed in table 2 .

The 1-month measurements differed significantly from the preoperative measurements in terms of the root mean square (RMS; $p=0.05$ ), higher-order RMS (HORMS; $p=0.023)$, astigmatism $(p=0.02)$, and trefoil $(p=0.033)$. No differences were observed in coma $(p=0.386)$ and SA ( $p=0.947)$. When the 3-month results were evaluated, only the total RMS $(p=0.020)$ and HORMS $(p=0.012)$ differed significantly. No statistically significant differences were observed between the preoperative and 3-month postoperative measurements of coma $(p=0.847), S A(p=0.630)$, trefoil $(p=0.847)$, and astigmatism $(p=0.102)$. Similarly, the 1 - and 3-month SIA results did not differ significantly $(p=0.854)$.

The correlations between the CH and CRF values and postoperative HOCAs and SIAs are presented in table 3.

Except for a positive correlation between the 3-month postoperative $\mathrm{CH}$ and $\mathrm{SA}$, no relationships were observed between the preoperative and 1 - and 3-month postoperative values of $\mathrm{CH} / \mathrm{CRF}$, total RMS, HORMS, astigmatism, coma, trefoil, SA, and SIA. Figures 1 and 2 demonstrate the relationship between $\mathrm{CH} / \mathrm{CRF}$ and SIA, and figure 3 presents the relationship between $\mathrm{CH}$ and $\mathrm{SA}$ at 3-months postoperatively.

\section{DISCUSSION}

The achievement of optimum visual outcomes from premium cataract surgery relies on accurate and reliable predictions of the re-

\section{Table 1. Demographic characteristics of study patients}

\begin{tabular}{lc}
\hline Characteristic & Value \\
\hline Sex (male/female) & $28.00(13 / 18)$ \\
Age, years (mean \pm SD) & $64.00 \pm 12.60$ \\
Eye (right/left) & $12 / 16$ \\
CDVA, logMAR (mean \pm SD) & $0.63 \pm 0.22$ \\
\hline
\end{tabular}

$\mathrm{SD}=$ standard deviation; $\mathrm{CDVA}=$ corrected distance visual acuity; logMAR= logarithm of the minimal angle of resolution.

Table 2. Preoperative and postoperative corneal aberrations and surgically-induced astigmatism

\begin{tabular}{lccc}
\hline Parameters & Preoperative & $\begin{array}{c}\text { Postoperative } \\
\text { 1-month }\end{array}$ & $\begin{array}{c}\text { Postoperative } \\
\text { 3-month }\end{array}$ \\
\hline TCA RMS $(\mu)$ & $1.323 \pm 0.231$ & $1.827 \pm 0.511$ & $1.598 \pm 0.382$ \\
HOCA RMS $(\mu)$ & $0.510 \pm 0.123$ & $0.911 \pm 0.372$ & $0.745 \pm 0.224$ \\
Astigmatism $(D)$ & $0.230 \pm 0.126$ & $1.122 \pm 0.726$ & $0.848 \pm 0.577$ \\
Coma $(\mu)$ & $0.235 \pm 0.127$ & $0.291 \pm 0.107$ & $0.275 \pm 0.158$ \\
Trefoil $(\mu)$ & $0.297 \pm 0.208$ & $0.607 \pm 0.287$ & $0.351 \pm 0.262$ \\
SA $(\mu)$ & $0.274 \pm 0.139$ & $0.291 \pm 0.221$ & $0.232 \pm 0.124$ \\
SIA (D) & & $0.850 \pm 0.420$ & $0.760 \pm 0.330$ \\
\hline
\end{tabular}

TCA = total corneal aberration; $\mathrm{HOCA}=$ higher order corneal aberration; RMS= root mean square; $D=$ diopter; $S A=$ spherical aberration; $S I A=$ surgically induced astigmatism. 
fractive results ${ }^{(5)}$. Residual ametropia, especially astigmatism, is among the main causes (64\%) of dissatisfaction after implantation of a multifocal $I O L^{(9)}$. Therefore, recommendations suggest the correction of astigmatism $>1.0 \mathrm{D}$ before implanting a multifocal $I O L^{(7)}$. Previous findings have indicated that both astigmatism and aberrations might affect the visual quality of patients with multifocal IOLs. For instance, one study found that anterior coma values $>0.32 \mu \mathrm{m}$ might result in intolerable dysphotopsia in the presence of a diffractive multifocal IOL (A). Implantation of a premium IOL necessitates high anticipated postoperative refractive results; however, even under ideal circumstances, unexpected refractive deviations may be observed. Accordingly, with this study we aimed to investigate postoperative

Table 3. Correlation between preoperative corneal hysteresis/corneal resistance factor values and postoperative higher-order corneal aberrations and surgically-induced astigmatism

\begin{tabular}{lll}
\hline Parameters & CH & CRF \\
\hline Postoperative 1-month & & \\
TCA RMS $(\mu)$ & 0.086 & -0.143 \\
HOCA RMS $(\mu)$ & 0.029 & -0.086 \\
Astigmatism (D) & 0.106 & 0.524 \\
Coma $(\mu)$ & 0.312 & 0.109 \\
Trefoil $(\mu)$ & 0.322 & 0.112 \\
SA $(\mu)$ & 0.617 & 0.186 \\
SIA (D) & 0.067 & 0.067 \\
Postoperative 3-month & & \\
TCA RMS $(\mu)$ & -0.108 & -0.190 \\
HOCA RMS $(\mu)$ & -0.228 & -0.119 \\
Astigmatism (D) & 0.024 & 0.429 \\
Coma $(\mu)$ & 0.048 & 0.238 \\
Trefoil $(\mu)$ & -0.587 & -0.262 \\
SA $(\mu)$ & $\mathbf{0 . 8 5 0 *}$ & 0.071 \\
SIA (D) & -0.021 & 0.033 \\
\hline TCA tota corn
\end{tabular}

$\mathrm{TCA}=$ total corneal aberration; HOCA = higher order corneal aberration, RMS= root mean square; $D=$ diopter; $S \mid A=$ surgically-induced astigmatism; $S A=$ spherical aberration. ${ }^{*}$ Correlation is significant at a p value of $<0.05$.

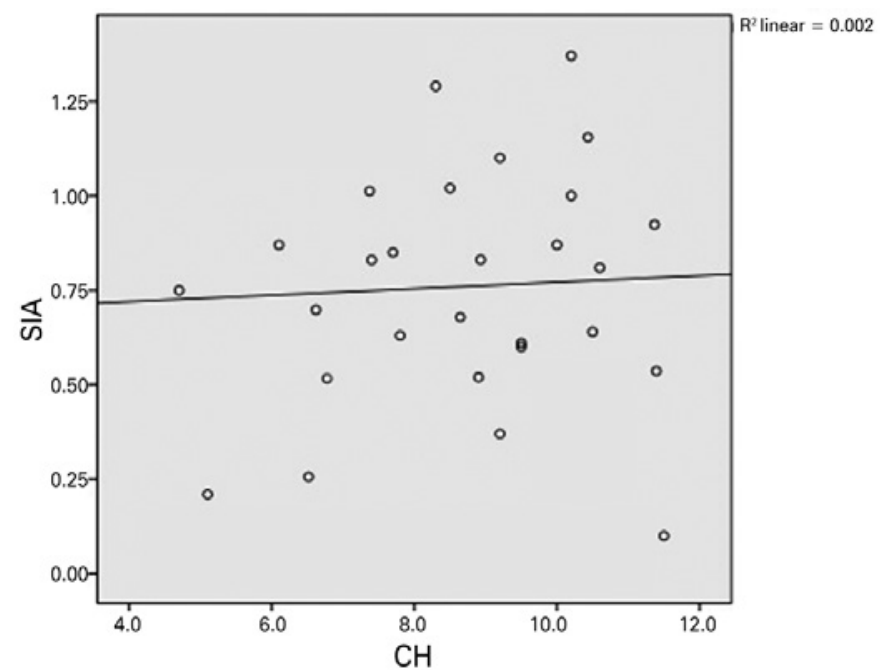

Figure 1. Relationship between corneal hysteresis and surgically-induced astigmatism at 3 months. refractive changes and the relationships between these changes and corneal biomechanical features in a cohort of patients with low-level astigmatism, as these are favorable candidates for multifocal IOL implantation.

In previous studies, a 3.2-mm incision had a significant impact on astigmatism and trefoil, but no significant effect on SA and coma during a 45-day postoperative follow-up ${ }^{(10,11)}$. However, these aberrations normalized after 3 months $^{(12)}$. After micro-incisional surgery ( $\leq 2-\mathrm{mm}$ incision), no significant changes were observed in any of the aberrations at 3 months of follow-up ${ }^{(3,13)}$. Therefore, our postoperative follow-up period was limited to 3 months. Similarly, we observed that astigmatism, trefoil, total RMS, and HORMS increased significantly within the first month, although no significant changes were observed in coma and SA. However, at 3 months, the incidence of all of these aberrations decreased, whereas the total RMS and HORMS increased significantly relative to the preoperative values.

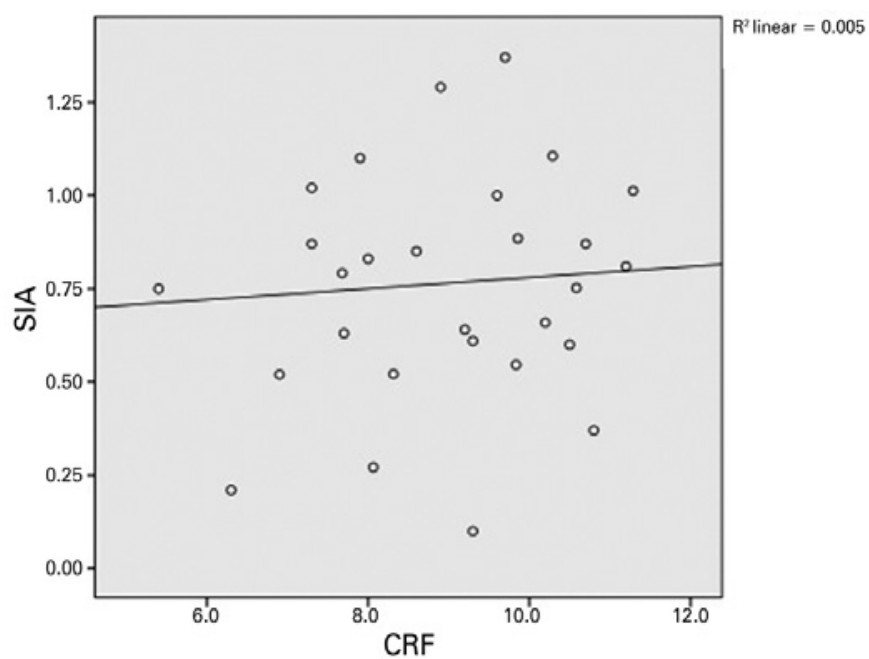

Figure 2. Relationship between the corneal resistance factor and surgically-induced astigmatism at 3 months.

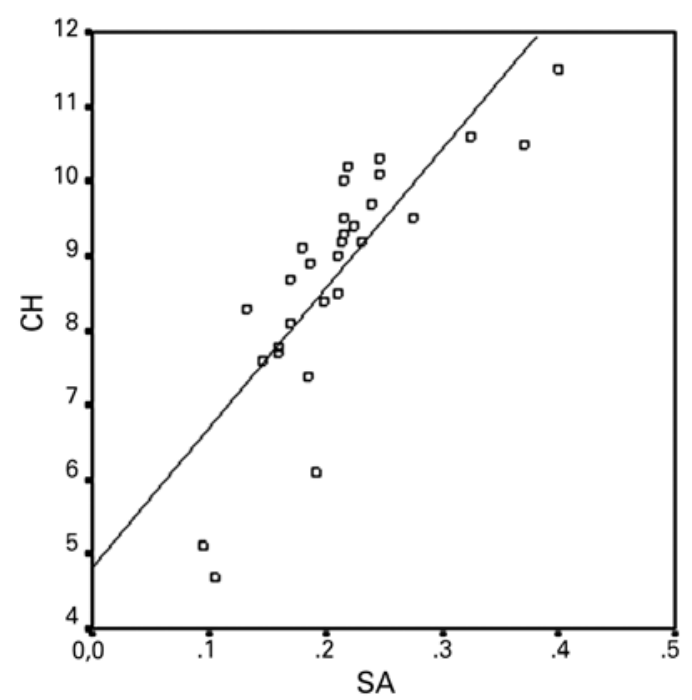

Figure 3. Relationship between corneal hysteresis and spherical aberration at 3 months. 
The incision size is one factor that affects the extent of SIA after cataract surgery. In our study, which implemented 2.8-mm incisions, we observed SIAs of $0.85 \mathrm{D}$ in the first month and $0.76 \mathrm{D}$ in the third month. In other words, these SIA results did not differ significantly. Previous studies that used similar incision sizes reported different SIA values. A study by Hayashi et al., in which a $2.65-\mathrm{mm}$ incision size was used for cataract surgery, reported a final incision size as $2.84 \mathrm{~mm}$ and 2-month SIA of $0.74 \mathrm{D}^{(14)}$. Another study that used a $2.75-\mathrm{mm}$ incision reported a 2-month postoperative SIA of $0.31 \mathrm{D}^{(15)}$. In summary, both studies found that the SIA decreased with the incision size.

The incision location also affects the level of SIA. Compared with superior incisions, temporal incisions are associated with a lower level of SIA and are accordingly used for patients with low-level astigmatism $^{(16)}$. In our study, we used superior incisions even though our patients had a low-level astigmatism. This might explain the high level of SIA identified in our study. The use of temporal incisions might have reduced the SIA.

Similar to SIA, corneal aberrations that developed after cataract surgerywerefound to be closely related to the incision size. Specifically, the aberrations decreased with decreasing incision size (a) should be replaced with ${ }^{(14)}$. According to our findings following the creation of 2.8-mm incisions, in the third month the total RMS and HORMS increased significantly from the preoperative values. Although trefoil and astigmatism increased at 1 month postoperatively; these values decreased at 3 months and approached the preoperative values. Given these decreases in trefoil and astigmatism, the aberration-induced dissatisfaction experienced by multifocal IOL-implanted patients might decrease by 3 months postoperatively.

Numerous studies have investigated the effects of incision location and size on postoperative changes in refraction and aberrations; however, few studies have investigated the effects of corneal biomechanical features on SIA and HOCAs. Denoyer et al. published the first such unique study and observed positive correlations among the preoperative $\mathrm{CH}, \mathrm{CRF}$, and $\mathrm{SIA}$ in the first month ${ }^{(5)}$. This correlation is represented by the following formula: $\mathrm{SIA}(D)=2.08+$ $0.24 \times$ Incision Size $(\mathrm{mm})-0.19 \times \mathrm{CH}(\mathrm{mmHg})$. Denoyer et al. did not observe a correlation between the preoperative $\mathrm{CH}$ and $\mathrm{CRF}$ and the postoperative HOCAs. In our study, we did not find a relationship between the preoperative $\mathrm{CH} / \mathrm{CRF}$ and postoperative SIA/HOCAs. We merely noted a positive correlation between the $\mathrm{CH}$ and $\mathrm{SA}$ at 3 months. According to this result, the formation of SA increases as the $\mathrm{CH}$ increases or the corneal hardness decreases after surgery. Because the corneal biomechanical resistance is lower in patients with a high $\mathrm{CH}$, greater postoperative disruption of corneal sphericity may be observed. Awareness of this potential outcome may be needed when an aspheric IOL is selected. These two studies differ in terms of characteristics of the patient cohort; notably, patients with a low level of astigmatism $(<0.50 \mathrm{D})$ are more suitable candidates for multifocal IOL implantation. In addition, we extended the follow-up duration to 3 months.

Our study had some limitations. First, the incision size was not measured at the end of surgery. However, the incision size may expand during surgery, especially when an $I O L$ is implanted. Second, aberrations were assessed using a Pentacam and not an aberrometer. However, analyses of the repeatability of the Pentacam for the measurement of aberrations have yielded conflicting data ${ }^{(17)}$. Third, because of the low number of patients, we were unable to evaluate whether the patients abided by the astigmatism rule, and could not investigate correlations with surgical results or the effects of posterior surface astigmatism.

In conclusion, our results regarding the relationship between corneal biomechanical properties and SIA differ from those of the original study published on this topic. Accordingly, further prospective studies involving larger patient groups are needed. This relationship might help us to understand the incidence of unexpected astigmatism after cataract surgery and explain the unexpected refractive aberrations and ectasias that may occur after corneal refractive procedures.

\section{Other Cited MATeRIAL}

Hamza I, Aly MG, Hashem KA. Multifocal IOL Dissatisfaction in patients with high coma aberrations. Presented at: ASCRS symposium on Cataract, IOL, and Refractive Surgery, 2011 March. San Diego, California.

\section{REFERENCES}

1. Portaliou DM, Grentzelos MA, Pallikaris IG. Multicomponent intraocular lens implantation: two-year follow-up. J Cataract Refract Surg. 2013;39(4):578-84.

2. Zheleznyak L, Kim MJ, MacRae S, Yoon G. Impact of corneal aberrations on through-focus image quality of presbyopia-correcting intraocular lenses using an adaptive optics bench system. J Cataract Refract Surg. 2012;38(10):1724-33.

3. Yao K, Tang X, Ye P. Corneal astigmatism, high order aberrations, and optical quality after cataract surgery: microincision versus small incision. J Refract Surg. 2006;22(9): 1079-82.

4. Tejedor J, Murube J. Choosing the location of corneal incision based on pre-existing astigmatism in phacoemulsification. Am J Ophthalmol. 2005;139(5):767-76.

5. Denoyer A, Ricaud X, Van Went C, Labbé A, Baudouin C. Influence of corneal biomechanical properties on surgically induced astigmatism in cataract surgery. J Cataract Refract Surg. 2013;39(8):1204-10.

6. Villegas EA, Alcón E, Artal P. Minimum amount of astigmatism that should be corrected. J Cataract Refract Surg. 2014;40(1):13-19.

7. Hayashi K, Manabe S-i, Yoshida M, Hayashi H. Effect of astigmatism on visual acuity in eyes with a diffractive multifocal intraocular lens. J Cataract Refract Surg. 2010;36(8): 1323-29.

8. Kotecha A, Oddone F, Sinapis C, Elsheikh A, Sinapis D, Sinapis A, et al. Corneal biomechanical characteristics in patients with diabetes mellitus. J Cataract Refract Surg. 2010;36(11):1822-8

9. Braga-Mele R, Chang D, Dewey S, Foster G, Henderson BA, Hill W, Hoffman R, Little B, Mamalis N, Oetting T, Serafano D, Talley-Rostov A, Vasavada A, Yoo S; ASCRS Cataract Clinical Committee. Multifocal intraocular lenses: relative indications and contraindications for implantation. J Cataract Refract Surg. 2014;40(2):313-22.

10. Guirao A, Tejedor J, Artal P. Corneal aberrations before and after small-incision cataract surgery. Invest Ophthalmol Vis Sci. 2004;45(12):4312-9.

11. Marcos $S$, Rosales $P$, Llorente $L$, Jiménez-Alfaro I. Change in corneal aberrations after cataract surgery with 2 types of aspherical intraocular lenses. J Cataract Refract Surg. 2007;33(2):217-26.

12. Hayashi $\mathrm{K}$, Hayashi $\mathrm{H}$, Oshika T, Hayashi F. Fourier analysis of irregular astigmatism after implantation of 3 types of intraocular lenses. J Cataract Refract Surg. 2000; 26(10): 1510-6.

13. Elkady B, Alió JL, Ortiz D, Montalbán R. Corneal aberrations after microincision cataract surgery. J Cataract Refract Surg. 2008;34(1):40-5.

14. Hayashi K, Yoshida M, Hayashi H. Postoperative corneal shape changes: microincision versus small-incision coaxial cataract surgery. J Cataract Refract Surg. 2009;35(2):233-9. Comment in: J Cataract Refract Surg. 2009;35(2):205

15. Kurz S, Krummenauer F, Gabriel P, Pfeiffer N, Dick HB. Biaxial microincision versus coaxial small-incision clear cornea cataract surgery. Ophthalmology. 2006;113(10): 1818-26.

16. Hashemi H, Khabazkhoob M, Soroush S, Shariati R, Miraftab M, Yekta A. The location of incision in cataract surgery and its impact on induced astigmatism. Curr Opin Ophthalmol. 2016;27(1):58-64

17. Greenstein SA, Fry KL, Hersh MJ, Hersh PS. Higher-order aberrations after corneal collagen crosslinking for keratoconus and corneal ectasia. J Cataract Refract Surg 2012; 38 : 292-302. 